\title{
A literatura e suas modalidades de amor: um enfoque psicanalítico
}

\author{
Literature and its modality of love: \\ a psychoanalytic approach
}

\section{Ernesto Söhnle}

Universidade de Santa Cruz do Sul - UNISC - Santa Cruz do Sul - Rio Grande do Sul - Brasil

Resumo: A psicanálise sempre precisou da arte, em especial da literatura, mas também, das artes plásticas e cênicas para revelar o que a teoria não consegue ver, por representar as estruturas e procedimentos do funcionamento psíquico e social. Nestes termos, Lacan vai ler este amor primordial, que é o amor pela própria imagem, sob o signo do mito de Narciso, assim como o amor transferencial, tematizado por Freud, será conjugado sob o signo do Banquete, seja como suposição de saber, que nada sabe além do desejo de Alcebíades por Agatão, seja como discurso do mestre, por alocar o amor philia no lugar do agalmasedutório. A psicanálise, também vai abordar o amor trágico a partir da lição de Antígona, aquela que deu até aquilo que não tinha, em nome da dignidade humana. Já o amor-paixão será articulado sob a rubrica do bovarismo, expressão romântica de uma aspiração amorosa que, em malogro, vai desembocar na melancolia, como antessala da morte. O amor cômico, na pena de Molière, será o amor que rebaixa o Outro, justamente para que o sujeito não se obrigue a morrer de amor. O amor ao pensamento será articulado nos termos daquele que ama o próprio amor, cujo modelo será o amor cortês provençal. Enfim, no derradeiro Lacan, será o amor de Beatriz que iluminará o caminho sublimatório de Dante em direção à significação vazia do amor eterno. Por tudo isto Lacan irá nos lembrar, em sua homenagem a Marguerite Duras, que o artista sempre irá preceder o psicanalista nos trilhamentos do inaudito, tanto no que se refere ao saber, quanto ao amor...

Palavras-chave: Amor.Literatura. Psicanálise.

Abstract: Psychoanalysis has always needed art, in special literature, but also, visual and scenic art to reveal what theory cannot see, by representing structures and procedures of psychical and social functioning. In these terms, Lacan will read this primordial love, which is the love of his own reflection, under the sign of Narcissus myth, as well as the transferential love, themed by Freud, will be calledunder the sign of Symposium, being as an assumption of knowledge, that knows nothing beyond Alcibiades' desire for Agathon, or as the master's speech, for assigning the love philia in place of the seductive agalma. The psychoanalysis will also address the tragic love from Antigone's lesson, the one who gave even what she did not have, in name of human dignity. Whereas the love-passion comes under the heading bovarysme, romantic expression of a loving desire that, in frustration, will end up on melancholy, as a prelude to death. The comic love, on Molière's sentence, will be the love that degrades the Other, so that the individual does not require the death of love. The love for thinking comes in terms of the one who loves the love itself, whose model will be the Provencal courtly love. At last, on Lacan, Beatrice's love will illuminate Dante's sublimation path towards the empty meaning of eternal love. For that, Lacan will remind us, in his homage to Marguerite Duras, that the artist will always precede the psychoanalyst on unknown paths, both in relation to knowledge and love...

Keywords: Love. Literature. Psychoanalysis. 
Lacan, em 1972, no seminário O saber do psicanalista, nos disse que o discurso do capitalista tira de cena as coisas do amor. Um ano depois, em Televisão, Lacan nos disse que a saída para o discurso do capitalista seria a sublimação. O mestre de Paris estava se referindo ali ao joyceano amor pelo nome próprio ${ }^{1}$. Ou não foi o "santo nome" de Joyce, via sublimação, o exemplo lacaniano de contraveneno ao discurso do capitalista?

Mas, na conjuntura atual, nos cabe perguntar, se em uma sociedade pós-traumática, pós-clássica portanto, onde o neosujeito parece incapaz de purificar seus afetos pela ab-reação da katharsis, ${ }^{2}$ por se mostrar indiferente e/ou imune às coisas do amor, inclusive em seu viés sublimatório, como fazer resistência a este discurso que triunfa segundo Lacan? Se o discurso do mestre colocava o pensamento autoral no lugar do gozo, assim como certo discurso medieval colocou o amor no lugar da inexistência da relação sexual (esta última uma suposição de união absoluta), o discurso antimetafísico do capitalista coloca a acumulação no lugar do gozo particularizado dos sujeitos.

Ou seja, este discurso globalizado toma o gozo e/ou o discurso alheio como se fosse seu e o

\footnotetext{
1 O nome Aimée (amada), conferido transferencialmente, por Lacan, a sua célebre paciente, via ego auxiliar (suporte que o analista oferece para dissolver o núcleo egoico-agressivo do delírio), funcionou como uma metáfora substitutiva, pela produção sublimatória do artifício, com valor de nomeação sintomática. Já em Joyce, foi a escrita que serviu a reestruturação sublimatória de seu ego. Estruturalmente falando, o ego de Joyce foi diretamente afetado por uma falha estrutural e escrever foi a sua maneira sublimatória de suturar esta falha (inclusive no que concerne a exclusão paterna). Aliás, foi no episódio da agressão desferida por colegas, narrada por Joyce em Portrait of the artist as a youngman, que Joyce nos oferece o testemunho da simbolização de uma coisa que poderia ter sido traumática, na medida em que ele se distanciou sublimatoriamente de seu corpo violentado, deixando-o cair como se fosse uma casca. Então, esse ego desconstituído pulsionalmente estará presente na gênese da sublimação e a sublimação se presentificará na gênese de sua obra. Ou seja, o ego corretor de Joyce não funciona pela via da imagem corporal, ou do corpo pulsional, mas pela via da escrita sublimatória, que produz um nome público, amado como a si mesmo, enquanto lugar próprio da eternidade.

Freud acreditava que o falante, no complexo de Édipo, iria se comportar como se fosse um espectador da peça Édipo Rei, supondo e/ou temendo que o mesmo pudesse acontecer com ele, se compadecendo da sorte do herói. Por isso 0 complexo de Édipo, equivale à identificação com o drama do herói e significa castração simbólica, estrutura que refreia o gozo incestuoso, colocando neste lugar o amor pela Lei-do-Pai, que foi vertido pelo "não matarás" judaicocristão. A castração simbólica, enquanto assunção deste limite, evita a traumática mutilação do corpo, representada no Édipo em Colona, pela transposição do espaço do Ate.
}

transforma num significante contábil, petrificado pelo fetichismo dos gadgets. Ora, este sujeito assim abduzido - que vemos percorrer as mais variadas formas de inibição, tédio e melancolia ${ }^{3}$, tendo por horizonte o Ate da acefalia e do desengajamento existencial, enquanto recusa de fazer luto do impossível - é capaz de resistir ao referido discurso? Se a apatia pós-moderna, como nova versão daquilo que restou de Auchwitz, se afasta cada vez mais da atitude cético-filosófica de resistência, seu caráter de desistência pode denunciar o naufrágio do discurso da sublimação e do amor, na era da ciência. Mas, como nos ensinou Machado de Assis - que soube elevar o amor, tanto em sua corrente terna, quanto em sua corrente sensualista, ao mais alto grau da reflexão literária - ao discurso vencedor as batatas, pelo menos enquanto houver pensamento que singularize o gozo e represente o amor, do contrário vejamos:

Se o poeta Vinicius de Moraes (1974), em Carta ao Tom 74, tomou a melancolia como impulso, para nos ensinar que: “... só resta uma certeza, é preciso acabar com esta tristeza; é preciso inventar um novo amor", depreendemos daí que o amor é uma invenção, em termos lacanianos, uma elucubração com (a)língua. O amor é um esforço para significar o olhar do objeto amado e, qual Dante, fazer desta flechada uma ficção de amor. Por outro lado, ainda que amar possa se converter em uma invenção de sentido sobre a causa-a-ser, parece existir um saber impossível sobre o amor, pois "quem ama nunca sabe o que ama, nem sabe por que ama, nem o que é amar". (PESSOA, 2010, p. 34-5)

Ainda que vivido como um sentimento, o amor é um confuso bricabraque de signos linguísticos, podendo ser escrito em completude (Poros) e/ou em

\footnotetext{
3 Vale lembrar que na melancolia clínica, o sujeito é confrontado, desde a origem com uma impossibilidade de amor, impossibilidade do Outro primordial the transmitir o dom daquilo que não tem: a falta que gera o desejo, enquanto conjunto de forças que resistem à morte. A transmissão deste dom faculta ao infans a experiência de luto subjetivante, que gera o narcisismo primário, enquanto amor pela própria imagem, estrutura desmentida no melancólico. Ora, se o amor é o que vem em suplência a relação sexual, este sujeito não sustenta o amor pela própria imagem, nem realiza o trabalho simbólico de luto que poderia colocá-lo na via da castração, muito menos na via sublime, de seu $3^{\circ}$ e mais raro tipo, que Freud denominou sublimação do artista.
} 
penúria (Penia). Neste último caso, enquanto formulação lacaniana mais geral, teríamos o dar 0 que não se tem, que pode ser conjugado sob o signo de Antígona, cujo amor trágico cedeu a própria vida por respeito à Lei Divina. Haveria maior dom que dizer não à própria vida em nome do amor à dignidade humana? Mas, devido à conjugação deste Eros em penúria - ainda que em nome do amor ao Outro simbólico, que leva Antígona a não ceder sob seu desejo - nos deparamos com o telos melancólico da tragédia, que surge como Tânatus, em face do destino da heroína. Ainda que o amor possa fazer o desejo condescender ao gozo.

De qualquer forma, em Relação de objeto, Lacan (1995, p. 143) irá ver o amor como o símbolo da morte da Coisa que, por isto, "só pode ser [dom de] nada". Ora, se a morte da Coisa é o amor, este é o "dom daquilo que não se tem", que é dado "em troca de nada" (LACAN, 1995, p. 142, 151). Até porque, como lembra Allouch (2010, p. 109), na lógica do dom, "nunca é tanto um objeto que se dá quanto um signo [...] daquilo que não se tem". Ou seja, por detrás do que é dado, subsiste o que lhe falta: o falo incorpóreo (conjunto de forças que resistiram à morte). Esta seria a lição de amor trágico de Antígona, que não cedeu à tirania de Creonte por amor à Lei de Deus, não abrindo mão do desejo de dar ao irmão o direito à sepultura.

Ainda no âmbito da tradição ática, só que dialetizando os elogios de Fedro, Pausânias, Aristófanes, Erixímaco e Agatão, Sócrates evocou o discurso de Diotima, a sacerdotisa que the ensinou sobre a fenomenologia amorosa, pois ele reconhecia haver um impossível saber sobre o amor. Talvez por isto, a visão lacaniana do amor como "dom que não se tem", ao não se coadunar com a utopia de plenitude amorosa (de dois fazer Um), se articula à retórica interpretativa e dialogal socrático-platônica que, diante do amor-paixão de Alcebíades (ilusão de completude suposta na fusão da beleza com 0 prazer), respondeu com a falta, enquanto expressão deste furo irredutível no saber sobre o amor.

Assim, como ensinou Diotima, o amor não é bonito ou feio, nem mau ou bom, muito menos divino ou mortal, mas um gênio, originário de um engendramento entre Poros e Penia, por ocasião do natalício de Afrodite. Eu diria, com a permissão da sacerdotisa, que o amor é uma ficção linguageira, um termo médio capaz de (re)ligar o divino e o mundano. O efeito desta origem híbrida, que contracena sabedoria e ignorância, seria o poder, conferido ao amor, de interpretar e transmitir o divino aos homens e expressar o humano em termos divinos, o que explica a gênese da magia, da arte e da filosofia. Mais ainda, se "o amor é filósofo", como quer Diotima, isto não seria um eco da ancestralidade do modelo épico ${ }^{4}$ de Homero, "que estava perfeitamente consciente de que Gnósis era Eros e que Eros era Gnósis", como sublinhou Sthepen Reckert (2001, p. 226-227). De qualquer forma, por ser o termo méatimor tende ao saber, pela justa medida de sua ignorância, quando repercute como desejo de saber. Este desejo de saber gera o esforço sublimatório do pensamento, que nada mais é que a expressão do amor pela verdade, consagrado nas artes, nas religiões e nas ciências. O mito de sua carência, que explica a inclinação do amor ao saber, na forma de linguagem reflexiva, vai responder pelo estatuto do belo (do espírito em Hegel), que pode adquirir uma condição universal e imortal neste mundo mortal.

Segundo Diotima, evocada por Platão (2005, p. 156-7), se a beleza transitória dos corpos enamorados, através das peripécias do amor-paixão, engendra um novo ser, que é a continuação do velho, o amor espiritual é capaz de parturiar, pelo "estudo, como se de nós estivesse saindo o conhecimento" um

\footnotetext{
4 Se a origem do modelo de transmissão dos seletos, incorporado pela psicanálise, pode ser buscada no pensamento dos filósofos remanescentes do período mítico, que se auto intitulavam amigos do saber, Platão no seu texto utópico denominado: A república os irá propor, enquanto governantes do Estado ideal, condicionado ao banimento dos poetas. Ali, buscando consagrar pedagogicamente o saber filosófico como uma nova Paidéia (apolínea), supostamente isolada do "vício" do princípio do prazer, abraçado pela alma irracional (dionisíaca), Platão questionou o saber da poesia épica. Contudo, como já demonstrou Antônio S. Mendonça (2005), antes de contrapor a "virtude" da razão as aparências da paixão, pela equivocação dubidativa do agalma, conforme a dialética socrático-platónica, o modelo épico já havia convertido Gnósis em Eros, até o ponto de fundi-los. Isto se daria, tanto n' A llíada, em que o "elogio à guerra" vinculava um conhecimento mítico sobre a superioridade do homem grego (ainda que Gnósis acabe sendo transmitido por Eros em penúria: Tânatus, em face da degradação da guerra), quanto na Odisseia, onde o tema da "volta ao lar" repercute o saber como Ágape, no reconhecimento sublimatório do herói por Penélope.
} 
saber simbolicamente superior (Belo), porque perene e de alcance social mais amplo, pela sua gênese sublimatória. Os discursos assim gerados são, também, filhos do amor espiritual, que nos aproximam de uma realidade mais elevada, pela via ético-estética do pensamento.

De forma análoga à ficção socrático-platônica, Lacan nos ensinou que o amor está no nível mais fundamental do "dar o que não se tem" inclusive por vir em suplência a uma aspiração impossível: a ilusão de completude que acredita fazer um de dois ${ }^{5}$, aspecto que ele articulou à inexistência da relação sexual, conforme Mais, ainda (sessão de 16 de janeiro de 1973). Ou seja, o amor seria o luto dessa relação sexual (impossível), que transforma o "não cessa de não se escrever", no contingente, mas não menos ficcional "cessa de não se escrever", como quer Jean Allouch (2010).

Contudo, o amor, tomado em sua concepção mais geral, nos leva ao seu fundamento: o amor narcísico, amor que se situa sob o signo do autoerotismo de Narciso, visto que a ousia ${ }^{6}$ que se desprendeu da Coisa morta foi libidinalmente investida na imagem do corpo próprio, gerando o amor pela própria imagem. Ou seja, o sujeito se identifica ali com o conjunto de forças que resistiram à morte da Coisa. No entanto, este amor de si deve circular como amor ao diverso, do contrário nos deparamos com a morte da alteridade (simbólica), expressa na indiferença e/ou imunidade para com a imagem do semelhante, presente no dito Mal de Narciso. Sabe-se, a partir do mito, que tal forma idólatra de amor pelo próprio reflexo embriaga os vivos de morte. Neste sentido, o lago de Eco pode ser entendido, não somente como uma metáfora do primeiro espelho, mas como uma alegoria da substância-vida auto-erótica, que não se desdobrou

\footnotetext{
5 Esta suposição mitológica de completude nos remete ao elogio de Aristófones, n' O banquete, em que a ira ciumenta de Zeus, provocada pela arrogância de seus filhos andróginos, rompeu definitivamente a indivisibilidade do Uno primitivo, ao bipartir este ser originariamente pleno em duas metades. Sendo que, no lugar exato da inexistência dessa união integral (presumida, também, pela via da relação sexual), entraria a aspiração impossível de fazer um do amor-paixão, quando em confluência com qualquer narrativa ilusória de completude no Ocidente.

${ }^{6}$ Substância essencial do ser.
}

em amor alo-erótico, enquanto conjunto de forças que resistem à morte. Malgrado isto, por trás do gozo incestuoso com o próprio reflexo (vide Pausânias), Narciso se deparou com a ymage da Morte, enquanto face inefável dessa Coisa inumana de onde, paradoxalmente, transborda a vida (zoe), libido em estado puro, não-simbolizada.

Contudo, o homem vai insistir na ilusão de completude do amor, no reestabelecimento de um todo primitivo (conforme o mito de Aristófanes), renovado pela promessa romântica de felicidade plena. No pathos amoroso, enquanto excesso, desmesura e enceguecimento, inclusive no plano sexual, ocorre uma idealização do objeto amado à custa do empobrecimento do amor-próprio. Nos termos deste querer loucamente o que não se obtém, Lacan, não desprezou a afirmação freudiana de que o louco ama seu delírio como a si mesmo. No delírio de amor é possível "se abolir como sujeito, na medida em que ele admite uma heterogeneidade radical do Outro. Mas este amor também é um amor morto" (LACAN, 2002, p. 287). Ou seja, neste amor extremo ocorre a idolatria do Outro hiperbolizado, ora enquanto signo de virtude, ora como símbolo do prazer sexual, à custa do desaparecimento destrutivo do próprio sujeito. Em suma, neste amor delirante poderemos ter, ou o excesso do amor erótico, ou o excesso do amor sublimado, jamais os dois em relação dialética, isto é, um sendo limitado pelo outro e vice versa.

Assim, malgrado o fantasma romântico, que aspirava a completude do amor, toda paixão impossível comporta pelo menos um desfecho possível: a melancolia, vide os Sofrimentos do jovem Werther, bem como a epidemia de suicídios que se produziu na esteira da publicação do romance de Goethe. A própria anatomia da heroína bovárica nos leva àquela que morre de amor, em vista da decepção fálica com os rumos passionais de seu desejo, na medida em que declina do homem autorizado pelas regras sociais, em função do proibido. Seu destino trágico nos lembra que o gozo masoquista da Cousa amada (dasDing), vale dizer, a busca, pela via transgressiva, desse impossível e 
obscuro objeto de gozo esbarra na punição moral (psicológica e/ou social), seu efeito melancólico possível, como antessala da morte. É isto que nos ensinou a escrita romântica, realista e naturalista, em: A dama das camélias, Madame Bovary, O primo Basílio, ThérèseRaquin etc. $E$, ainda que Freud desabonasse a tese de uma degenerescência hereditária, supostamente abraçada por Zola, via Charcot, em função da realidade psíquica, tal literatura soube ilustrar muito bem o caráter nãosublimado das exigências pulsionais, agressivas e sexuais, bem como seu empuxo a aniquilação, pela via do bovarismo passional e moral.

Na contramão disso teríamos o amor enquanto sentimento cômico, na medida em que ele rebaixa o Outro (radical), por servir à necessidade e iludir o desejo. Este seria o serviço prestado pelo "amor naïf, o amor ingênuo, o amor que une dois jovens em geral bem bobões" (LACAN,1999, p. 136).O autor se refere à ingenuidade do jovem Horácio e, principalmente à puerilidade da jovem Agnès, de $A$ escola de mulheres (Molière, 1662). Esta última que, justamente por sua ingenuidade, acabou se tornando muito mais perigosa em relação à ameaça fantasmática de Arnolf: "não ser corno". Neste sentido, o solteirão Arnolf é um "verdadeiro apaixonado" pois, obcecado pela ideia de não ser corno, supõe usar o amor como instrumento de satisfação, ao cultivar a ignorância de Agnès. Mas, por uma ironia do destino, acaba satisfazendo tolamente o gozo amoroso de outrem. Por sua vez, mesmo usando a linguagem de forma ingênua, mas de acordo com a satisfação de sua necessidade, Agnès sempre escapa ao controle de seu preceptor ancião. Arnolf, que se pretendia no controle do projeto educativo de Agnès, acaba ficando à mercê desta "integral de todos os equívocos", pois permite, não só que ela conviva com o "bobão" Horácio, mas colabora, sem saber, na traição.Momento em que declara, de forma risível, o seu amor, não se obrigando a matar e/ou morrer de amor diante do fracasso. Como arremata Allouch (2010, p. 124), o louco amor trágico do romantismo "é o cômico que funcionou mal. Reencontrar, tornar sensível o cômico do trágico", seria essa uma via de gaio saber, nãotodo, sobre o amor.

Em tempo, a psicanálise irá detectar outra modalidade de enamoramento, caracterizada por Freud como amor de transferência, que foi genealogicamente articulada por Lacan ao Banquete de Platão. Assim sendo, foi na estética de um de seus mais belos diálogos, que Platão pôs em circulação diversos discursos sobre o amor, coroados pelo elogio de Sócrates ao amor espiritual, num simpósio que celebrou o corpo, a beleza e o prazer - enquanto pano de fundo da paixão homo-erótica, característica da pederastia ática - bem como o discurso do mestre, enquanto forma superior de expressão do saber (Gnósis). Assim, em O banquete, veremos Sócrates se abster do lugar sedutório de agalma(da verdade integral, metaforizada em seu ventre), por recusá-lo, da parte de Alcebíades, propondo em seu lugar a falta, uma espécie de não-saber chamado ignorância platônica, que ressoou em Alcebíades como suposição de saber sobre o que lhe faltava.

Ou seja, ao não assumir a posse do precioso agalma (presunção de saber) cobiçado por Alcebíades, pois considerava que a sabedoria começa pelo reconhecimento da própria ignorância, Sócrates vai hiperdeterminar a eironeia - que em grego significa interrogar, fingindo ignorar, para dissolver as aparências fixadas em um imaginário ilusório - à maieutiké, que significa trazer à luz um saber inconsciente (recalcado), por reconstrução dialética, enquanto ato de elaboração da própriadoxa(opinião).Ao responder com o amor pela verdade à demanda passional de Alcebíades, Sócrates cria a possibilidade de seu conviva dar à luz a seus próprios pensamentos, ao provocar a verdade inconsciente e singular, implícita em sua doxa. Mais precisamente, o Sócrates do Simpósio, ao se esquivar do lugar de agalma (objeto causa do desejo), preservou o lugar de suposto saber, uma vez que Alcebíades enamorado reconheceu-o nesse lugar, ao ser confrontado com um saber sobre o seu próprio desejo por Agatão. Entretanto, Lacan irá manter distância da forma pedagógica com que Sócrates aponta o sentido do desejo de Alcebíades 
por Agatão; ainda que a sanha de Alcebíades possa nos ensinar algo sobre os limites da sublimação. De qualquer forma, será esta suposição de saber, obtida por equivocação dubidativa, a exemplo da arte de partejar, o índice principal do conceito lacaniano de transferência, que, conforme o Seminário 8, irá resgatar o que o amor transferencial de Freud tem de amor pela verdade do outro.

Procedimento que nos remete ao aforismo de Lacan: "amar é reconhecer a verdade do outro como sua", responsável pela possibilidade de escuta inconsciente a partir do lugar de sujeito suposto saber. E isto se daria na medida em que Sócrates, personagem, ao ocupar o lugar daquele que nada sabia além de Eros (amor e/ou desejo pela verdade), provocava, ao mesmo tempo que se esquivava de Alcebíades, tanto uma paixão ${ }^{7}$ transferencial, quanto um furo no saber, que nenhum saber universal é capaz de suturar. Portanto, esse amor de transferência, que significa para Lacan suposição de saber, tem origem na estética d' $O$ Banquete de Platão, onde o amor pela verdade de Sócrates, ao repercutir como reconhecimento da verdade do outro, convida o sujeito a amar o seu inconsciente como a si mesmo.

Isto nos remete a outra modalidade de amor, já não no âmbito de uma filosofia dos seletos, mas no âmbito dos grupos e das massas. Trata-se do liame amoroso dos grupos para com a figura, a princípio simbólica, do mestre (moderno), colocada no lugar de Ideal de ego destes sujeitos, que pode ser tanto o intelectual $^{8}$, quanto o político. Cabe lembrar que o

\footnotetext{
7 Trata-se da transferência do lado do analisando, equivalente ao termo enamoramento, que hiperdetermina amor-paixão (Eros em abundância) + suposição de saber. E, ainda que Sócrates, ao ser colocado no lugar de objeto causa de desejo, tenha ascendido, por via histérica, ao lugar de suposição de saber,provocando tanto a transferência, quanto a mestria, um analista não é mestre, apenas objeto a investido de suposição de saber.

${ }^{8}$ Vide o discurso fílmico de $A$ onda (Dennis Gansel, 2008), onde um professor de ensino médio, assumindo o funcionamento egoico do princípio do líder, tenta demonstrar, num projeto escolar, a estruturação de laços amorosos que levam sujeitos aparentemente desengajados a abraçar a lógica do totalitarismo (sacrifício a deuses obscuros), reproduzindo o contexto do Holocausto na Alemanha nazista, que imolou o bode expiatório mais próximo. Surpreendentemente, Die Welle foi baseada em uma primeira versão televisiva de The Wave, do diretor Grasshoff (1981), inspirada na onda totalitária que realmente arrebatou os estudantes de uma escola secundária norteamericana, em Palo Alto, Califórnia, nos idos de 1967.
}

Ideal de ego é o lugar dos ideais culturais e dos exemplos simbólico-sublimatórios oferecidas pela civilização. Porém, quando esta figura de mestria, em tese redentora e unificadora, troca o simbólico caráter interpretativo e transmissivo (relativo, por via sublimatória, ao pensamento, ao Geist), pela megalomania do poder, ela passa a funcionar como um Outro moral, cujo fundamento mítico é encontrado no superegoico pai da horda primitiva, em seu imperativo: a Lei-do-Gozo. Este Outro não-castrado seria a encarnação do superego natural, aos moldes do a priori moral do imperativo categórico kantiano, que se situa aquém da subjetivação simbólica do superego freudiano. Ou melhor, o que o líder totalitário formula, a partir o imperativo categórico de Kant, como necessidade de sacrifício de gozo, evoca o grito primevo do Ser Supremo em Malignidade ficcionado por Sade: Goza!

Contudo, o superego não é inato, como pensava Kant, mas um legado transmitido pelo amor (Ágape) paterno, como ensinou Freud. Explicando melhor, onde há dependência primária (Abhängigkeit) entre o infans (não-falante) e seus Outros, o animal humano irá experimentar, fatalmente, o sentimento de desamparo (Hieflosigkeit), de onde brota a angústia de perda do amor. Esta angústia (no âmbito do Liebesverlust ${ }^{9}$ ) é operativa na instauração do superego, que não é inato, mas estruturado subjetivamente na relação com os primeiros outros, tornando-se o censor das pulsões agressivas e sexuais. Assim, em função do receio da perda do amor dos pais, o freio moral externo, responsável pelo rechaço do gozo (Triebverzicht), é introjetado pelo sujeito. Por isto Freud caracterizou o superego como herdeiro do complexo de Édipo (na castração).

Malgrado isto, num contexto traumático (de irrupção do real) - em que o espanto (schreck) e o medo (furcht) dominam uma nação derrotada - o desamparo se torna desespero. Com efeito, o simbólico Ideal de ego, representado por um mestre, pode ser desmentido em nome de um "pai" real, que irá funcionar como consciência moral. Tal superego

\footnotetext{
${ }^{9}$ Angustvon der Liebesverlust (angústia de perda de amor)
} 
natural, encarnado por uma figura de exceção, pode operar no sentido inverso ao programa da cultura, que sob o signo de Eros, visa à reunificação psíquica e civilizatória em torno do amor, à custa do rechaço do gozo com a barbárie.

$\mathrm{Na}$ esfera política, trata-se do culto à personalidade, que na esfera mercadológica, desliza para o culto à personalidade atraente, hoje mera celebridade. Na esfera ideológica, o superego natural, emanado de um pai real, por exemplo, de um líder político como Adolf Hitler, fomenta o gozo do sacrifício, que leva à guerra e à desagregação psíquica e civilizatória. Por isto Freud nos ensinou que é mais fácil unir massas em torno do gozo do ódio, mediante uma forma de laço libidinal com o líder, do que em nome do amor a Lei-do-Pai, que em psicanálise tem valor legiferante de "Não matarás". Aqui estaríamos diante de uma forma pervesificada de amor, que se consolida no ódio ao "estrangeiro". Nestes termos, ali onde o projeto cultural e civilizatório espera encontrar Eros, como expressão do amor capaz de congregar os indivíduos em uma coletividade, ele se depara com Tânatus, a se manifestar pela dor, pela dispersão e pela morte. Já o discurso das celebridades pode exercer a ditadura da moda, que dissemina o ódio à subjetividade e ao pensamento próprio.

$\mathrm{Na}$ contra mão disso, podemos evocar um sentido medieval conferido ao amor, que surge no século XI, prolongando-se até o início do século XIII, cuja ascese apoia-se numa escolástica do sofrimento, por ser o objeto, não só idealizado artificialmente, mas interditado artificiosamente, exigindo todo um refinamento das palavras e uma elegância nos atos e nos gestos de amor, como vemos em Tristão e Isolda, em O romance da rosa (Guillaume de Lorris), ou mesmo em Lancelot (Chrétien de Troyes). Não seria esta uma leitura devocional do amor como dom que não se obtém? Em todo caso, trata-se do amor cortês provençal e de seus poetas cantores, chamados trovadores, no sul da França, destacadamente na região de Languedoc, ou de troveiros, na França do Norte e de Minnesänger na Alemanha. Sua influência atingiu, também, a Inglaterra e determinados domínios espanhóis.

A função das técnicas do amor cortês era interditar a Dama, por elevá-la a dignidade de Coisa, isto é, a dignidade de objeto sublime e inatingível (inclusive por álibis sociais e geográficos), sendo a impossibilidade da relação sexual (ali explicitada), suprida por esta forma elegante de abstinência sexual:

[O amor cortês] é uma maneira inteiramente refinada de suprir a ausência de relação sexual, fingindo que somos nós que lhe pomos obstáculo. [...] O amor cortês é, para o homem, cuja dama era inteiramente [...] a sujeita, a única maneira de sair com elegância da ausência da relação sexual (LACAN, 1985, p. 94).

Isto porque, na poesia provençal e palaciana das cantigas de amor, a Cousa amada é representada sublimatoriamente como um vazio, ainda que a Dama seja sua figuração. No ato poético o trovador brinca com o prazer de experimentar o desprazer da privação deste objeto inacessível e impessoal (das Ding). Ou seja, ali o objeto despersonalizado, a Domnei, a Dama(aquela que domina), por isto, em galego-português, Mi Dom (meu Senhor), é introduzido pela porta da interdição, da privação, sendo "que todos parecem dirigir-se a mesma pessoa"(LACAN, 1997, p. 185). Ou seja, todos dirigem-se a mesma Coisa impossível, enigmática (daí o Segredo e o Senhal) e desumana (pois ela é tão caprichosa nas provas que impõe aquele que está aos seus serviços, quanto cruel em sua Sanha). Uma barreira cerca e isola a Dama divinizada, que na poesia só pode ser amada no plano da devoção, cabendo ao servidor abster-se sexualmente de seus favores, o que, em termos lacanianos, corresponde simbolicamente ao reconhecimento da impossibilidade da relação sexual.

Paradoxalmente, Lacan chega a reconhecer, neste joi d'amor extremo, estância da renúncia e da beatitude do amor, uma função ética do erotismo, ao cogitar do gozo derivado das técnicas de retenção e suspensão do amor interruptus, visto que o iniciado 
deve passar por etapas precisas de autodisciplina fenhedor (o aspirante que apenas suspira), precator (que pode suplicar o amor) e entendedor (cujo amor é reconhecido pela Dama) - antes de tornar-se o amante (drut) que, na fugacidade do osculum (beijo da amizade), ascende à reunião da misericórdia:

as etapas que o amor cortês propõe antes do que é chamado muito misteriosamente - não sabemos no fim das contas o que era - de dom de misericórdia, se articulam aproximadamente com o que Freud teoriza em seu Três ensaios como sendo da ordem dos prazeres preliminares(LACAN, 1997, p 189).

Mas, o amante abstém-se do objeto amado, não do amor, daí que no amor cortês ama-se o próprio amor. Por isto, ao falar do amor cortês no Seminário 7, Lacan destaca a sublimação, ou Mito do Amor (conforme Michel Silvestre), que ele chama de verdadeiro amor. No mito desse amor de versão medieval, a sublimação também é o termo médio entre o amor erótico (desejo) e a Coisa (impossível), capaz de transmutar o imaginário do amor (amorpaixão) em poesia. Em termos gerais, é o que faz o artista que, segundo Freud, deserotiza o objeto, por conceder-Ihe a dignidade de coisa sublime, enquanto obra de arte. No amor, enquanto Mito do Amor, amase sublimatoriamente o próprio amor, por lhe conferir um estrutura de ficção que bem-diz a verdade sintomática, na medida em que se des-refere ao objeto de carne e osso e refere-se a Coisa simultaneamente.

Não estaria aí, implícita, a lição platônica de Diotima sobre o amor pela verdade, que Lacan chama de "verdadeiro amor"? Não é disto que se trata quando ela diz que o amor é filósofo, ou seja, é um mestre capaz de converter a penúria do desvario carnal na ficção reunificadora do amor espiritual (ligando o divino ao humano e vice-versa)?

Então, esta linda canção de amor, difere da certeza de Vinícius (inventar uma nova paixão), pois instaura uma nostalgia que, como bem lembrou Alain Didier-Weill (2014, p. 63), citando Vitor Hugo, "é a felicidade de estar triste", pois o objeto de que ela nos fala, sempre irá faltar ao encontro por ser tão impossível quanto o real. Porém, este objeto impossível se faz presente por se vaporizar poeticamente no céu dos significantes... Ou a arte alquímica está errada ao definir a sublimação como a passagem de um sólido ao estado vaporoso, onde podemos usufruir do perfume da Cousa primordial, justamente por gozar de seu caráter incorpóreo?

Mas, nem tudo é somente sublimação e/ou, do ponto de vista do cavaleiro, inibição sexual, no campo do amor cortês. E, mesmo criticado por ser convencional e insincero, o amor cortês - que, a juízo de Agamben (2007), foi capaz de enodar borromeanamente o desejo, a fantasia e a linguagem poética $^{10}$ - é uma forma extremamente refinada de referenciar este vazio significante, vale dizer, a ausência da completude pelo sexual, enquanto via possível de união espiritual com o objeto amado.

Porém, num caso específico, o amador pode transitar do lugar de inibição, diante de um objeto impossível, para o lugar desejante, em face de um objeto sexualmente possível, conjugado seu amor sob o signo da goichemai non fina ${ }^{11}$, no âmbito de um gaio saber. Trata-se do Amadis de Gaula ${ }^{12}$, em que a

\footnotetext{
10 "Na prática poética, entendida como significação do inspirar de amor, Narciso consegue efetivamente apropriar-se da própria imagem e saciar o seu folamour, em um círculo no qual o fantasma gera o desejo, o desejo se traduz em palavras, e a palavra delimita um espaço [ficcional] onde se torna possível a apropriação daquilo que, do contrário, não poderia ser nem apropriado, nem gozado" (AGAMBEN, 2007, p. 212).

11 "Alegria que nunca acaba"

12 Refere-se à história de amor de Amadis de Gaula pela filha do Rei Lisuarte, Oriana. Amadis nasce sem o reconhecimento da paternidade pelo caráter pecaminoso de sua concepção. Mesmo depois do casamento de seus pais, o cavaleiro Periom de Gaula e Elisena, filha do Rei Garinter da pequena Bretanha, a falta de paternidade não é reparada, pois o pequeno Amadis foi abandonado ao mar. Esta falta paterna persiste, apesar do herói ter sido encontrado e criado pelo cavaleiro Gandales, junto do filho deste, Gandalim e adotado pelo Rei Languines, da Escócia. A esposa de Languines acolhe o donzel do mar e o coloca a serviço da infanta Oriana, que ali se encontra hospedada. Amadis começa a nutrir pela jovem, de quem é pajem, uma verdadeira adoração, acabando por consagrar sua vida aos serviços da Dama amada. A inibição o impede de se declarar, mas quando ele o faz o casal decide manter em segredo este amor. Porém, o fato de ter sido criado por Gandalim, adotado Languines, acolhido pela família de Oriana e sagrado cavaleiro por Periom irá suturar, apenas provisoriamente, sua falta paterna. Amadis vai, então, em busca de suas verdadeiras origens, lançando-se na conquista do sucesso na ordem equestre, enquanto pré-requisito de sedução da Dama. Enfrenta as mais fantásticas aventuras, protegido por Urganda, a desconhecida e perseguido pelo mago Arcalaus, realizando todas as façanhas em nome do amor a Oriana. Até porque, mesmo sagrado cavaleiro, ele não foi reconhecido na condição de filho pelo rei Periom. Deste modo, não sendo reconhecido como filho de um rei, Amadis só poderia ser legitimado na linhagem de sua amada se desse origem a um
} 
versão provençal do mito do amor é ultrapassada em função do reconhecimento heterossexual da paternidade. Mais ainda, tal narrativa pode ser vista como transmissora do amor em um sentido mais amplo, pois ali o gozo da Dama produz um sentido gaio, consagrado como produção de gozo fálico, de edípica alegria:

\begin{abstract}
na inscrição do casamento enquanto 'reconhecimento da paternidade', reconhecimento da mestria portada pelas damas ao fazerem com que os cavaleiros se deparem com a diferença sexual. Assim, bravura, mesura, conquista e reconhecimento, nesta ordem, reconciliam o Amadis com a referência paterna que, ocupará este lugar, por produzir um pretendente. Reconhecer-se filho de um Rei (ungido, Periom de Gaula) por gerar um Rei - outro (neto de Lisuarte), é o seu destino sintomático (MENDONÇA, 1993, p. 217-218).
\end{abstract}

Este fazer da vida uma obra, compatível com a criação de uma "alegria que não finda" no Amadis de Gaula, se articula, ora com o amor-narcísico pela própria imagem (reconhecimento da formosura do Donzel do Mar, obtenção da Arete que Ihe consagra no lugar viril da gesta heroica e da glória equestre), ora com o amor pelo próprio amor (no inicial e sublimatório serviço à Dama), ora com o amor heterossexual (desejo correspondido por Oriana), que leva ao reconhecimento de seu lugar de homem pela mulher amada (requisito que atende à recomposição do Nome-do-Pai, pela via da descendência). Então, como já demonstrou o autor acima citado, este joi d' amor no Amadis de Gaula, não se limita a conduta inibitória, de abstenção sexual, no que concerne ao culto amoroso à Dama, enquanto objeto inatingível do fin'amors, mas diz respeito ao ato de bem-dizer, enquanto nomeação, sua linhagem, já que ali se trata de articular a sublimatória gesta heroica à

outro rei. Suporta todo tipo de agruras, de provas de privação até que, por permissão de Oriana, gera-lhe dois filhos. Contudo, é injustamente repudiado pelos ciúmes (sanha) da amada e, mesmo vencendo seu rival (Patim), abandona a cavalaria, tornado-se eremita, na companhia do velho Andalope. É perdoado por Oriana, que lhe resgata pelo reconhecimento da paternidade, sendo incluído nesta linhagem, não sem antes voltar à glória equestre. Amadis corre em defesa de Oriana, vence a guerra com os romanos, já reconciliado com Lisuarte. Seu prestígio declina somente na medida em que o prestígio de seu filho Esplandiam aumenta. Por fim, Amadis pode bem-dizer o futuro do filho, que não terá que passar pelas mesmas agruras que ele passou. recomposição da paternidade. Então, tal forma singular de amor cortês perpetra seu sentido gaio na produção de um amor narcisicamente estruturado, de edípica inclusão, na inscrição do casamento, que levou ao reconhecimento da paternidade. Com efeito, o amor heterossexual dirigido a uma única damasujeita salva o herói da falta paterna, por dar-lhe um filho (Esplandiam), resgatando, em forma e conteúdo, o Santo Graal de seu sintoma familiar.

Por último, existiria ainda uma forma de amor que separa o que o Amadis uniu, teorizada por Lacan em sua conferência intitulada: "Mito individual do neurótico" e retomada no escrito: "A significação do falo". Em sua primeira intervenção, Lacan (1952) aponta um conflito, pertinente ao Homem dos Ratos (codinome de um célebre analisando de Freud), entre a significação valorizada por seu pai da "mulher rica", confrontada com significação depreciada por este, da "mulher pobre" (a mulher mundana, justamente a mulher desejada pelo paciente de Freud). Já em "A significação do falo", Lacan (1989, p. 702)retoma esta divergência inscrita no objeto amoroso, que pode ser significado "de diversas maneiras, quer como virgem, quer como prostituta", o que nos remete as "Contribuições à psicologia do amor II", em que Freud (1996, p. 190)sublinha a inibição amorosa de homens que "quando amam, não desejam, e quando desejam, não podem amar". Isso ao contrário de Dom Juan, aquele que ama as mulheres, uma a uma, segundo Lacan.

Já a frustração do neurótico de Freud residiria na impossibilidade de conciliar os dois valores psíquicos do objeto amoroso: um representado pelo lugar da mulher supervalorizada, por vezes transfigurada moralmente na mãe e/ou na santa e, em geral, detentora dos vínculos legítimos (do casamento) e a outra mulher desvalorizada, a dirne ${ }^{13 \text {, }}$ a mulher ilegítima, mundana, de má reputação, em suma, a puta. Ali o amor sublime, ou como diz

\footnotetext{
13 Conforme Jacques-Alain Miller (2010), o termo Dirne (mulher pública, prostituta), em alemão antigo (Hochedeutsch) provemde Thiorna, que significa virgem, o que nos remete ao seu sentido antitético, assim como proposto por Freud em seu estudo do termo Heimlich.
} 
Freud $^{14}$, a corrente terna da libido estaria reservada à figura que representa a pureza, que remete à mãe (ainda que numa formação reativa contra a fantasia de incesto). À outra mulher estaria destinada a corrente sensual, o amor-paixão e o prazer sexual daí derivado, na forma de gozo, por vezes, em seu caráter mais obsceno. A música de Chico Buarque, "Geni e o zepelim", ilustra a dicotomia, ali irreconciliável, entre a figura da virgem redentora e da grande prostituta, na medida em que o mesmo objeto é clivado na bendita, donzela, ou na Dama Geni, porque sujeita da salvação da cidade e no seu contrário a Geni maldita, de má reputação, passível de ser depreciada por qualquer um.

Por isto, é comum, tanto na vida real, quanto na literatura, que esta suposta dirne seja objeto de difamação, o que pode ser uma versão d' A mulher, enquanto não-toda, para que ela possa ser tomada como uma mulher por um homem ${ }^{15}$, como no caso do personagem Nicolai, no conto de Tchékhov, que goza com a depreciação d' "A esposa", como forma de "possuí-la", ou pelo menos, de não abrir mão dela. Diante da inibição sexual masculina, só a mulher depreciada seria capaz de liberar as barreiras que refreiam as pulsões sexual e agressiva, em nome do mito do pudor materno.

Por outro lado, a atração pela mulher fatal, ou pela mulher do próximo, sob 0 imperativo transgressivo do mais-gozar atual ${ }^{16}$, pode representar o gozo com a mãe, A mulher proibida, que por este

\footnotetext{
${ }^{14}$ Freud nos oferece uma visão dualista do amor, em que a sua corrente terna nos leva, tanto a um Ágape ático (amor espiritualizado, partilhado pelos membros da família), quanto ao Ágape medieval (inclusive em sua dimensão de amor ao próximo). Por sua vez, o mesmo sentido ático nós aproxima de uma teoria medieval do amor chamada física, não corporal, fundamentada na Physis grega (responsável pela origem, essência e movimento de todas as coisas). Tal teoria espiritual foi preconizada por São Tomás de Aquino, cuja fonte era a Ética a Nicômaco de Aristóteles e sua representação seria o amor philia, o amor da amizade filosófica, que Lacan (1976) aproxima da ideia de amor eterno. A outra corrente, que Freud traduz como sexual, se aproxima de um viés menos reflexivo, porém mais lírico e poético, que é a teoria extática, introduzida por Abelardo, São Bernardo de Clairvaux, entre outros e responde pelo amor carnal, pelo desejo irracional, que pende à violência e à loucura

15 Cf. MILLER, J.-A. Minha garota e eu. Opção Lacaniana: online nova série. ano 1, no 2, julho de 2010.

${ }^{16}$ Em termos de metáfora cultural, é desse apetite mater(ial) de que nos fala Lacan (1972), em Milão, quando aponta um gozo de consumo/acumulação tão voraz que acaba se consumando, aos moldes do discurso fílmico de Pocilga, by Pasolini (1969).
}

motivo seduz. Ou a dama fatal, conforme a narrativa fílmica de Sin City (Rodrigues \& Miller, 2014), não é a mulher que ninguém pode ter, enquanto uma figuração da morte, que usa a sensualidade como tela de proteção contra seu vazio devorador?

Já o ciúme depreciativo pode ser efeito complementar da castração, como em Bentinho, que "preferiu" ver, nos olhos de ressaca de Capitu, não a marca do arrebatamento sexual - capaz de resgatá-lo da impotência do celibato - mas a marca da cigana oblíqua e dissimulada, em função de sua identificação ao desejo da mãe, que o queria destituído da referência fálica. Mas, a sua inibição sexual é diferente da dita inibição do pensamento ${ }^{17}$, apresentada por mestre Romão em "Cantiga dos Esponsais", conforme o conto de Machado de Assis. Ali, seu personagem era um músico virtuoso, mas incapaz de criar, sintoma que é intensificado a partir do falecimento da mulher amada. Mais ainda, diferentemente da analogia estrangeira, o personagem Bentinho poderia ser conceitualmente caracterizado, conforme o "Mito individual do neurótico", por sua dicotomia, própria do masoquismo moral, que divide os objetos entre sublimes e mundanos, por remeter-lhe ao lugar de "morto" em relação ao desejo, de onde podemos correlacionar o crime de existir hamletiano com o crime de desejar machadiano $^{18}$. Ou o fantasma do Rei, seu pai, também não faz Hamlet abrir mão de seu destino desejante (Ofélia), em função do paradoxal imperativo moral de não tocar na mãe Gertrudes (ainda que traidora) e, ao mesmo tempo, cumprir a vendetta (matar Cláudio, seu assassino)?

\footnotetext{
${ }^{17}$ Cf. MENDONÇA, Rita Franci. Machado de Assis e a metáfora melancólica da oblatividade. Berggasse 19: Revista Escola Lacaniana de Psicanálise, Rio de Janeiro, vol. 2, p. 85-94, 2010. ${ }^{18}$ Cf. CALDWELL, H. O Otelo brasileiro de Machado de Assis. Cotia: Atelié, 2002. Contudo,Hellen Caldwell não aborda o tema do ponto de vista da psicanálise, mas no nível da literatura comparada, associando Otelo a Bentinho. E, mesmo se tratando do binômio Shakespeare/Machado de Assis, ela não articula 0 personagem machadiano ao fantasma obsessivo (hamletiano), nem ao bovarismo, como fez MENDONÇA, A. S. Dom Casmuro, o bovarismo e a dissolução machadiana. In: Estudos Universitários de Língua e Literatura. Rio de Janeiro: Tempo Brasileiro, 1993.
} 
Enfim, ao falar do amor que não condescende ao desejo, visto que este último fracassa ${ }^{19}$ enquanto formação do inconsciente, o Lacan do L'insu evocou mais uma vez o ato poético como modelo de uma nova forma de interpretar, capaz de visar o real, isto é, "fazer ressoar outra coisa que não o sentido, [...] acrescentar o vazio"(MILLER, 2009, p. 183). É o que os ditos poéticos de Dante - que evocam o amor pela inalcançável Beatriz, que iluminou seu caminho em direção ao amor eterno - fazem ressoar como um efeito de furo, em função da impossibilidade da relação sexual, ao esvaziar a palavra do sentido, na condição de consagrá-la como uma significação vazia, isto é, enquanto um significante que articule ausência e não-senso:

Como o poeta pode realizar esta prova de força de fazer com que um sentido esteja ausente é, bem entendido, substituindo esse sentido ausente pelo que chamei a significação. [...] A significação é uma palavra vazia, é, em outras palavras, o que, a respeito de Dante, se exprime no qualificativo colocado sobre sua poesia, isto é, que ela seja amorosa. O amor nada é senão uma significação, vale dizer que ele é vazio, e vemos bem a maneira como Dante encarna essa significação, o desejo tem um sentido, mas o amor tal como dele já falei em meu seminário sobre a ética, tal como o amor cortês o suporta, é apenas uma significação. (LACAN, 1988, p. 49-50).

Mas, antes de questionarmos por que o desejo passa ao amor - nos confrontando com a ausência de sentido $^{20}$, cuja morte bem poderia ser o mestre

\footnotetext{
${ }^{19}$ Até porque não existe objeto sublime e/ou sexual capaz de satisfazer o desejo humano.

Em seu vigésimo seminário, intitulado: Mais, ainda, Lacan cogita do gozo místico como uma saída sublimatória do delírio (tido como mera falação), assim como já dissera da santidade sublimatória ser a saída para o discurso do capitalista. Lacan reconhece o gozo místico como uma expressão do puro amor (amor eterno), que propõe a sublimação da psicose, com os mesmos ingredientes do delírio. Ele nos dá como exemplo disso Santa Tereza d' Ávila e seus testemunhos místicos, assim como a literatura poética de São João da Cruz. Se a beata, assim como São João da Cruz tinham os delírios místicos em carne e osso, isso não faz questão para Lacan, porque o que ele está abordando ali é o discurso místico da acídia, enquanto uma expressão da união com Deus, no amor eterno. Tanto Santa Tereza d' Ávila, quanto São João deixaram obras em que descrevem um gozo sem-sentido, chamado místico, como descrito na devoção do êxtase (quarto estágio de elevação da alma). Nesse discurso eles estabelecem uma relação entre a jaculação mística, o luto de si e a fecundação do amor de Deus. $\mathrm{A}$ arte barroca produziu alegoria com isso, conforme a célebre escultura de Bernini: O êxtase de Santa Tereza, que representa o gozo espiritual da beata ao ser trespassada por uma seta do amor divino, arremessada por um anjo. Aliás, no barroco, que é
}

absoluto - poderíamos aprender como os trovadores a saber-fazer com o amor, amando-o como a nós mesmos, pois, como nos ensinou outro mestre amado, é "melhor experimentá-lo [eu diria gozá-lo] que julgáIo"...

\section{Referências}

AGAMBEN, Giorgio. Estâncias: a palavra e o fantasma na cultura ocidental. Belo Horizonte: UFMG, 2007.

ALLOUCH, Jean. O amor Lacan. Rio de Janeiro: Cia. de Freud, 2010.

DIDIER-WEILL, Alain. Nota azul. Rio de Janeiro: Contra Capa, 2014.

FREUD, Sigmund. Sobre a tendência universal à depreciação na esfera do amor. In: completas, vol. XI. Rio de Janeiro: Imago, 1996. Obras

LACAN, Jacques. O seminário, livro 3: as psicoses. $2^{\underline{a}}$ ed. Rio de Janeiro: Zahar, 2002.

O seminário, livro 4: a relação de objeto. Rio de Janeiro: Zahar, 1995.

O seminário, livro 5: as formações do inconsciente. Rio de Janeiro: Zahar, 1999.

O seminário, livro 7: a ética da psicanálise. Rio de Janeiro: Zahar, 1997.

O seminário, livro 8: a transferência. Rio de Janeiro: Zahar, 1992.

O seminário, livro 20: mais, ainda. Rio de Janeiro: Zahar, 1985.

O seminário, livro 24: L'insu que sait de L'une-bévues'aile à mourre. Buenos Aires: Escuela Freudiana de Buenos Aires, 1988 (não publicado).

O mito individual do neurótico. Rio de Janeiro: Zahar, 2008.

A significação do falo. In: Escritos. Rio de Janeiro: Zahar, 1989.

O aturdito. In Janeiro: Zahar, 2003.

Outros escritos. Rio de

um discurso melancólico, o símbolo da Fênix serviu de alegoria da ressureição da imagem do (corpo) morto aos olhos do leitor. Por isto, Lacan (1985, p. 158) nos disse que o êxtase "barroco é a regulação da alma pela escopia corporal", o que significa conferir valor de espírito a imagem do corpo morto, ou mortificado. Em suma, como toda narrativa que cultua o objeto morto, o barroquismo é um discurso melancólico, que não visava o luto (desejante), mas uma espécie de "luto espiritual" de si, através do arrebatamento sustentado pelo sublimatório amor eterno. 
MENDONÇA, Antônio SérgioO ensino de Lacan. Rio de Janeiro: Gryphus/Forense, 1993.

Dom Casmuro, o bovarismo e a dissolução machadiana. In: Estudos Universitários de Língua e Literatura. Rio de Janeiro: Tempo Brasileiro, 1993.

Os limites de uma erótica contida: literatura e/ou psicanálise? Opinião Acadêmica, №. 450, Rio de Janeiro, 2005. Disponível em: www.riototal.com.br/coojornal/antoniosergio025.htm. Acesso: 08 mar. 2014.

MENDONÇA, Rita Franci. Machado de Assis e a metáfora melancólica da oblatividade. Berggasse 19: Revista Escola Lacaniana de Psicanálise, Rio de Janeiro, vol. 2, 2010.

MILLER, Jacques-Alain. Minha garota e eu. Opção Lacaniana: online nova série. ano 1, no 2, julho de 2010.

Perspectivas sobre o Seminário 23. Rio de Janeiro: Zahar, 2009.

PESSOA, Fernando. O guardador de rebanhos. In:_. Poemas de Alberto Caeiro:obra poética II. Porto Alegre: L\&PM, 2010.

PLATÃO. O banquete, ou, do amor. $3^{a}$ ed. Rio de Janeiro: Difel, 2005.

RECKERT, Stephen. Más allá de las neblinas de noviembre. Madri: Gredos, 2001. 